\title{
Perspective
}

\section{Potential Mechanism for Pentachlorophenol-Induced Carcinogenicity: A Novel Mechanism for Metal-Independent Production of Hydroxyl Radicals}

\author{
Ben-Zhan Zhu* and Guo-Qiang Shan \\ State Key Laboratory of Environmental Chemistry and Ecotoxicology, Research Center for Eco-Environmental \\ Sciences, Chinese Academy of Sciences, Beijing 100085, P. R. China \\ Received January 28, 2009
}

\begin{abstract}
The hydroxyl radical $\left({ }^{\circ} \mathrm{OH}\right)$ has been considered to be one of the most reactive oxygen species produced in biological systems. It has been shown that ${ }^{\circ} \mathrm{OH}$ can cause DNA, protein, and lipid oxidation. One of the most widely accepted mechanisms for ${ }^{\circ} \mathrm{OH}$ production is through the transition metal-catalyzed Fenton reaction. Pentachlorophenol (PCP) was one of the most widely used biocides, primarily for wood preservation. PCP is now ubiquitously present in our environment and even found in people who are not occupationally exposed to it. PCP has been listed as a priority pollutant by the U.S. Environmental Protection Agency (EPA) and classified as a group 2B environmental carcinogen by the International Association for Research on Cancer (IARC). The genotoxicity of PCP has been attributed to its two major quinoid metabolites: tetrachlorohydroquinone and tetrachloro1,4-benzoquinone (TCBQ). Although the redox cycling of PCP quinoid metabolites to generate reactive oxygen species is believed to play an important role, the exact molecular mechanism underlying PCP genotoxicity is not clear. Using the salicylate hydroxylation assay and electron spin resonance (ESR) secondary spin-trapping methods, we found that ${ }^{\circ} \mathrm{OH}$ can be produced by TCBQ and $\mathrm{H}_{2} \mathrm{O}_{2}$ independent of transition metal ions. Further studies showed that TCBQ, but not its corresponding semiquinone radical, the tetrachlorosemiquinone radical (TCSQ ${ }^{*}$ ), is essential for ${ }^{\circ} \mathrm{OH}$ production. The major reaction product between TCBQ and $\mathrm{H}_{2} \mathrm{O}_{2}$ was identified to be trichloro-hydroxy-1,4benzoquinone (TrCBQ-OH), and $\mathrm{H}_{2} \mathrm{O}_{2}$ was found to be the source and origin of the oxygen atom inserted into this reaction product. On the basis of these data, we propose that ${ }^{\circ} \mathrm{OH}$ production by TCBQ and $\mathrm{H}_{2} \mathrm{O}_{2}$ is not through a semiquinone-dependent organic Fenton reaction but rather through the following novel mechanism: a nucleophilic attack of $\mathrm{H}_{2} \mathrm{O}_{2}$ to TCBQ, leading to the formation of an unstable trichloro-hydroperoxyl-1,4-benzoquinone (TrCBQ-OOH) intermediate, which decomposes homolytically to produce ${ }^{\circ} \mathrm{OH}$. These findings represent a novel mechanism of ${ }^{\circ} \mathrm{OH}$ formation not requiring the involvement of redox-active transition metal ions and may partly explain the potential carcinogenicity of the widely used biocides such as PCP and other polyhalogenated aromatic compounds.
\end{abstract}

\section{Contents}

1. Introduction

1.1. Pentachlorophenol (PCP) and Its Major Carcinogenic Metabolites

1.2. Molecular Mechanisms of PCP Metabolite- 971 Induced DNA Damage

1.3. Pro-oxidant vs Antioxidant Equilibrium

2. Mechanism of Protection by Desferrioxamine (DFO) against TCHQ-Induced DNA Damage

2.1. Protection by DFO against TCHQ-Induced DNA Damage Was Not Due to Its Binding of Iron but Rather to Its Scavenging of the Reactive TCSQ ${ }^{\circ}$

2.2. Protection by DFO against TCHQ-Induced Cyto- and Genotoxicity in Human Fibroblasts

3. Molecular Mechanism of PCP Metabolite-Induced Genotoxicity

3.1. Metal-Independent Production of ${ }^{\circ} \mathrm{OH}$ by PCP Metabolite and $\mathrm{H}_{2} \mathrm{O}_{2}$
3.2. Molecular Mechanism of Metal-Independent Production of ${ }^{\circ} \mathrm{OH}$ by PCP Metabolites and $\mathrm{H}_{2} \mathrm{O}_{2}$

4. Conclusions

976

\section{Introduction}

1.1. Pentachlorophenol (PCP) and Its Major Carcinogenic Metabolites. PCP is a major industrial and agricultural biocide that has been used primarily as a wood preservative (1). The annual production of PCP has been estimated to be about 46 million pounds in the United States (1). Because of its efficiency, broad spectrum, and low cost, PCP has also been used as an algaecide, bactericide, fungicide, herbicide, insecticide, and molluscicide $(1-3)$. In the United States, approximately $97 \%$ of PCP usage was as a wood preservative (1). The majority of U.S. use of PCP has been to preserve wooden

* To whom correspondence should be addressed. Tel: 86-10-62849030. Fax: 86-010-62923563. E-mail: bzhu@rcees.ac.cn. 
<smiles>Oc1c(Cl)c(Cl)c(Cl)c(Cl)c1Cl</smiles>

$$
\underset{\text { PCP }}{\mathrm{Cl}} \text { Redox-cycling } \rightarrow \text { ROS } \rightarrow \underset{\text { Damage }}{\text { DNA }}
$$

\section{Redox-cycling $\rightarrow$ ROS $\rightarrow$}<smiles>CC(C)COc1c(Cl)c(Cl)c(O)c(Cl)c1Cl</smiles>

TCHQ
Figure 1. PCP and its carcinogenic quinone and semiquinone metabolites.

poles for power transmission lines and other utilities. In China and other developing countries, PCP has also been used to kill snails to prevent snail fever. Its worldwide usage and relative stability make PCP an ubiquitous environmental pollutant (1-3). In fact, PCP has been detected in body fluids, such as human urine, serum, and milk, and tissues of people who are not occupationally exposed to it $(1-3)$. Extensive studies of PCP concentrations in body fluids (plasma or urine) of nonoccupationally exposed individuals have found average PCP concentrations of 40 parts per billion (ppb) (range, $0-1840 \mathrm{ppb}$ ). In contrast, in the blood of occupationally exposed workers, the median level of PCP was found to be as high as $19580 \mathrm{ppb}$ (range, 6000-45200 ppb) (3). Postmortem analysis of serum, tissue, and urine samples from individuals who died from PCP intoxication showed tissue PCP concentrations of 20-140 ppm (ppm) and urine concentrations of 28-96 ppm. The most likely source of exposure is PCP-treated wood products by way of the food chain. In groups of individuals who are not specifically exposed to PCP, net daily intake estimated in eight countries varied from 5 to $37 \mu \mathrm{g}$. Net intake was between 51 and $157 \mu \mathrm{g}$ per day in residents of homes made of PCP-treated logs (3). In individuals occupationally exposed to PCP, net daily intake varied widely, from 35 to about $24000 \mu \mathrm{g}$, depending on the type of work $(1-3)$. Human exposure to PCP can also originate, albeit to a minor extent, through metabolic formation from hexachlorobenzene or hexachlorocyclohexane, which are also ubiquitous environmental contaminants $(1-3)$.

PCP is a potent carcinogen. Following chronic exposure of $\mathrm{B} 6 \mathrm{C} 3 \mathrm{~F} 1$ mice to $\mathrm{PCP}$, hepatocellular carcinomas or adenomas, hemangiosarcomas, and phaeochromocytomas were observed (4). In a recent report, malignant mesothioma and nasal squamous cell carcinomas were induced in F334/N rats (5). In humans, malignant lymphoma and leukemia have been associated with occupational exposure to PCP $(1-3)$. PCP has been listed as a priority pollutant by the U.S. Environmental Protection Agency (EPA) and classified as a group 2B environmental carcinogen by the International Association for Research on Cancer (IARC) (1). While the precise mechanism of PCP's genotoxicity remains to be elucidated, it has been suggested that its quinone and semiquinone metabolites play an important role (Figure 1).

PCP is oxidatively dechlorinated to produce tetrachlorohydroquinone (TCHQ) by liver microsomal cytochrome P450s from rats and humans in vitro $(3,6)$ and by rodents in vivo (7-10). About $20 \%$ of PCP was recovered in the urine of PCPtreated $\mathrm{B} 6 \mathrm{C} 3 \mathrm{~F} 1$ mice as TCHQ and its glucuronide and sulfate conjugates (8). TCHQ can be further oxidized to tetrachloro-<smiles>CC(=O)CN(O)C(C)=O</smiles>

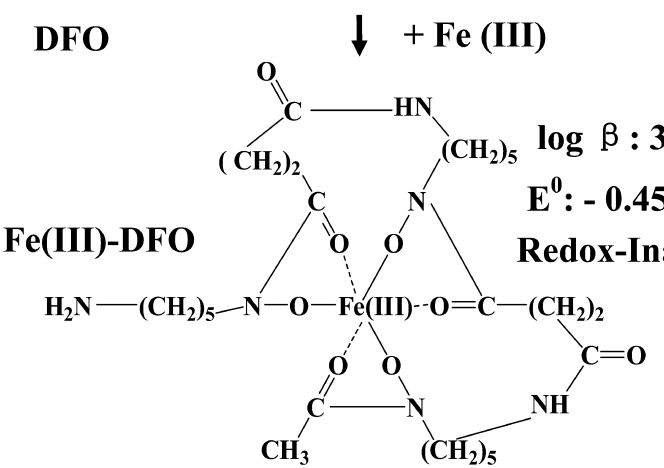

Figure 2. Chemical structures of DFO and its iron complex.
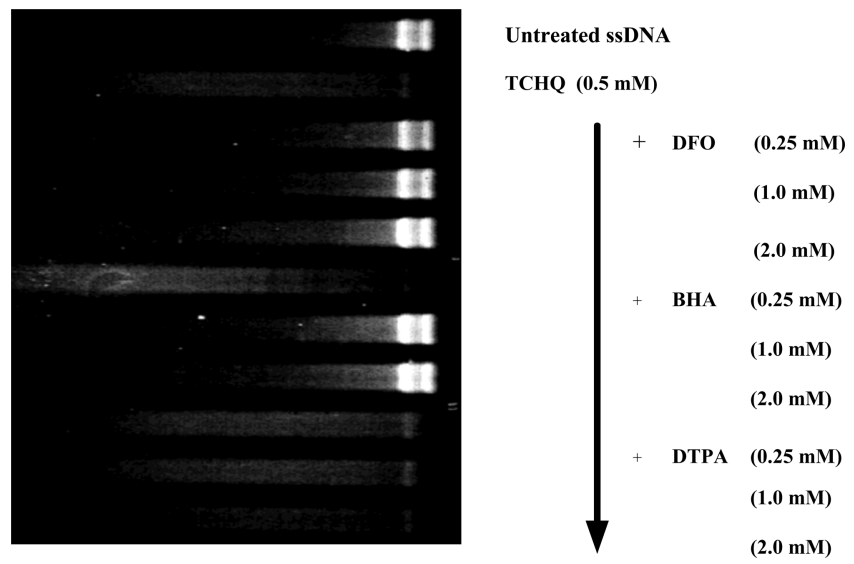

Figure 3. Protection by DFO, but not by DTPA, against TCHQ-induced DNA SSBs in isolated DNA (modified based on ref 32); BHA, benzohydroxamic acid.

1,4-benzoquinone (TCBQ) via its corresponding semiquinone, the tetrachlorosemiquinone radical (TCSQ*) (11). TCBQ and its thiol and glucuronide conjugates were also found in animals and humans $(6-10)$.

Redox cycling of compounds with a quinoid structure is a well-known phenomenon $(12,13)$. The cyclic (auto)oxidation and reduction reactions with the intermediary formation of semiquinone radicals can produce large amounts of reactive oxygen species (ROS) by reducing molecular oxygen to superoxide $\left(\mathrm{O}_{2}{ }^{--}\right)$, which in turn can induce oxidative stress $(12,13)$. However, it is generally accepted that $\mathrm{O}_{2}{ }^{--}$itself does not directly attack DNA but only after its dismutation to hydrogen peroxide $\left(\mathrm{H}_{2} \mathrm{O}_{2}\right)$ and subsequent metal-mediated cleavage to hydroxyl radical $\left({ }^{\circ} \mathrm{OH}\right)$. This reaction sequence is called the Haber-Weiss reaction or superoxide-driven Fenton reaction $(\mathrm{M}$ represents transition metals, especially iron and copper) (14):

$$
\begin{gathered}
2 \mathrm{O}_{2}^{\bullet-}+2 \mathrm{H}^{+} \rightarrow \mathrm{H}_{2} \mathrm{O}_{2}+\mathrm{O}_{2} \\
\mathrm{O}_{2}^{\bullet-}+\mathrm{M}^{n+} \rightarrow \mathrm{O}_{2}+\mathrm{M}^{(n-1)+} \\
\mathrm{H}_{2} \mathrm{O}_{2}+\mathrm{M}^{(n-1)+} \rightarrow \cdot \mathrm{OH}+\mathrm{OH}^{-}+\mathrm{M}^{n+}
\end{gathered}
$$

While PCP itself does not show any reactivity toward DNA, TCHQ was found to induce single strand breaks in isolated DNA (10), a variety of cell lines $(11,15-17)$, and liver of mice $(18,19)$. TCHQ also induced micronuclei and mutations at the 


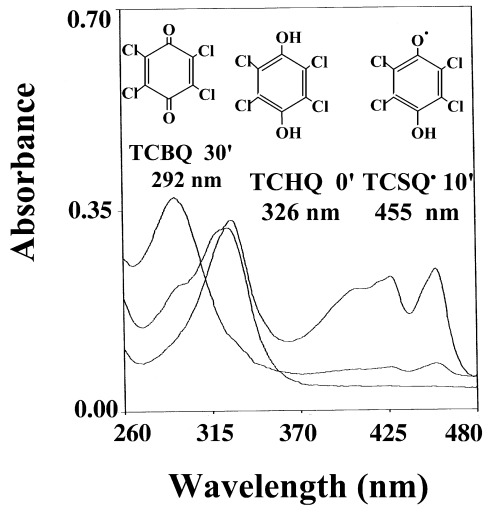

Figure 4. UV-visible spectral changes during TCHQ autoxidation (modified based on ref 32).

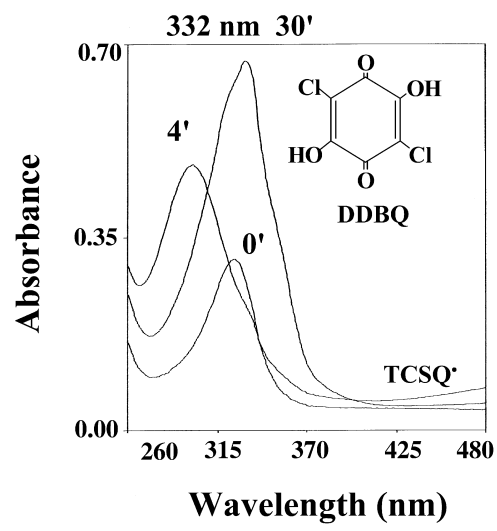

Figure 5. UV-visible spectral changes during TCHQ autoxidation with DFO (modified based on ref 26).

HPRT locus of V79 cells $(20,21)$ and the formation of 8-hydroxy-2'-deoxyguanosine (8-OH-dG) in V79 cells (22) and $\mathrm{B} 6 \mathrm{C} 3 \mathrm{~F} 1$ mice (18). At low concentrations, TCHQ reduced the colony-forming ability of human fibroblasts (15) and inhibited cell growth in CHO cells (17). Recently, TCHQ was found to induce the formation of direct adducts, AP sites, and oxidized bases in human HeLa S3 cells (23).

1.2. Molecular Mechanisms of PCP Metabolite-Induced DNA Damage. Both oxidative DNA damage and direct DNA adducts have been implicated in PCP-induced mouse liver carcinogenesis $(16,18,23)$. The most commonly analyzed biomarker of oxidative DNA damage, $8-\mathrm{OH}-\mathrm{dG}$, was detected in the livers of $\mathrm{B} 6 \mathrm{C} 3 \mathrm{~F}_{1}$ mice that received acute and subacute doses of PCP and TCHQ, and the levels were increased significantly over the corresponding controls (18). Recent findings in Fischer 344 rats that had been administered PCP for 27 weeks also revealed a statistically significant increase in 8-OH-dG in hepatic DNA over control (24). In addition to oxidized bases, it is likely that other types of oxidative DNA lesions are involved. Redox cycling of PCP quinoid metabolites to generate ROS is believed to play an important role in PCP genotoxicity.

Among $\mathrm{ROS},{ }^{\circ} \mathrm{OH}$ is regarded as the most reactive one produced in biological systems. DNA damage resulting from attack by ${ }^{\circ} \mathrm{OH}$ includes base oxidation, deoxyribose damage, strand breaks, and apurinic/apyrimidinic (AP) sites (14). ${ }^{\circ} \mathrm{OH}$ can induce AP sites by direct hydrogen abstraction from the sugar moiety of DNA, resulting in $5^{\prime}$-nicked oxidized AP sites formation (25-27). Another pathway for AP sites formation may involve depurination/depyrimidination of quinone-DNA adducts. TCBQ and its corresponding semiquinone radical are reactive electrophiles and, therefore, are also capable of alky- lating DNA and forming DNA adducts (24, 28, 29). Recently, Lin et al. showed (28) that low degree of oxidative and direct DNA damage was produced by high concentrations of TCBQ (1-5 mM). However, the molecular mechanisms underlying such damage are still unknown.

1.3. Pro-oxidant vs Antioxidant Equilibrium. The prooxidant potential of biological systems and their antioxidant capacity usually are in an approximate equilibrium (14). In normal cells, a primary defense against oxidative damage is provided by small molecule antioxidants such as glutathione (GSH) and ascorbate, which are present in millimolar concentrations. However, these defense mechanisms can be overwhelmed by xenobiotics such as PCP and its metabolites that induce the production of excessive ROS, which can result in damage to biological macromolecules such as DNA (12-14). It should be noted that the concentration of ROS, including $\mathrm{H}_{2} \mathrm{O}_{2}$, in cells under normal physiological conditions is low, but ROS concentration may be significantly increased in cells that are subjected to oxidative stress conditions such as exposure to PCP metabolites, as we showed recently in NIH 3T3 cells (30). TCHQ treatment was shown to cause more than $60 \% \mathrm{GSH}$ depletion in liver tissues of mice, possibly by forming GSH conjugates $(10,12,13$, and 19). It was suggested that depletion of GSH and other antioxidants by PCP metabolites could abolish the protective ability of the cell against ROS and lead to DNA damage (19). It is thus reasonable to hypothesize that PCP metabolite-induced DNA damage could be prevented if the levels of intracellular antioxidants were raised through supplementation of dietary antioxidants. Indeed, it has been demonstrated recently (31) that oral administration of antioxidant vitamin $\mathrm{E}$ and diallyl sulfide $3 \mathrm{~h}$ before each PCP challenge significantly protected against elevation of hepatic $8-\mathrm{OH}-\mathrm{dG}$ levels in male B6C3F1 mice, while vitamin $\mathrm{C}$, epigallocatechin gallate, and ellagic acid showed partial protection. These findings indicate that PCP-induced oxidative DNA damage in the target organ liver can be blocked by a number of dietary antioxidants.

\section{Mechanism of Protection by Desferrioxamine (DFO) against TCHQ-Induced DNA Damage}

2.1. Protection by DFO against TCHQ-Induced DNA Damage Was Not Due to Its Binding of Iron but Rather to Its Scavenging of the Reactive TCSQ: As discussed above, TCHQ has been identified as one of the main toxic metabolites of PCP. TCHQ can induce DNA single strand breaks and has also been implicated in PCP-associated genotoxicity. The ability of TCHQ to induce DNA damage has been previously attributed to its ability to form ${ }^{\circ} \mathrm{OH}$ through the classic metal-dependent Fenton reaction (see above). This notion was based on the fact that TCHQ-induced DNA damage was completely prevented by DFO (also called desferal and deferoxamine). DFO has been used as an iron chelating agent for the treatment of iron overload. This includes clinical cases of individuals who have ingested toxic oral doses of iron salts or require multiple blood transfusions, such as in the treatment of $\beta$-thalassaemia. DFO is a linear trihydroxamic acid siderophore that forms a kinetically and thermodynamically stable complex with ferric iron, ferrioxamine (Figure 2$)$. Its high binding constant $(\log \beta=31)$ and its redox properties $\left(E^{\circ}=-0.45 \mathrm{~V}\right)$ render the bound iron unreactive for the catalysis of oxygen radical production, as has been implicated in a variety of biological processes. It has been classically assessed that the prevention of damage by DFO was a sufficient proof for the role of loosely bound iron in the injurious processes. Although DFO has been repeatedly used to probe metal-catalyzed hydroxyl radical formation in biological 


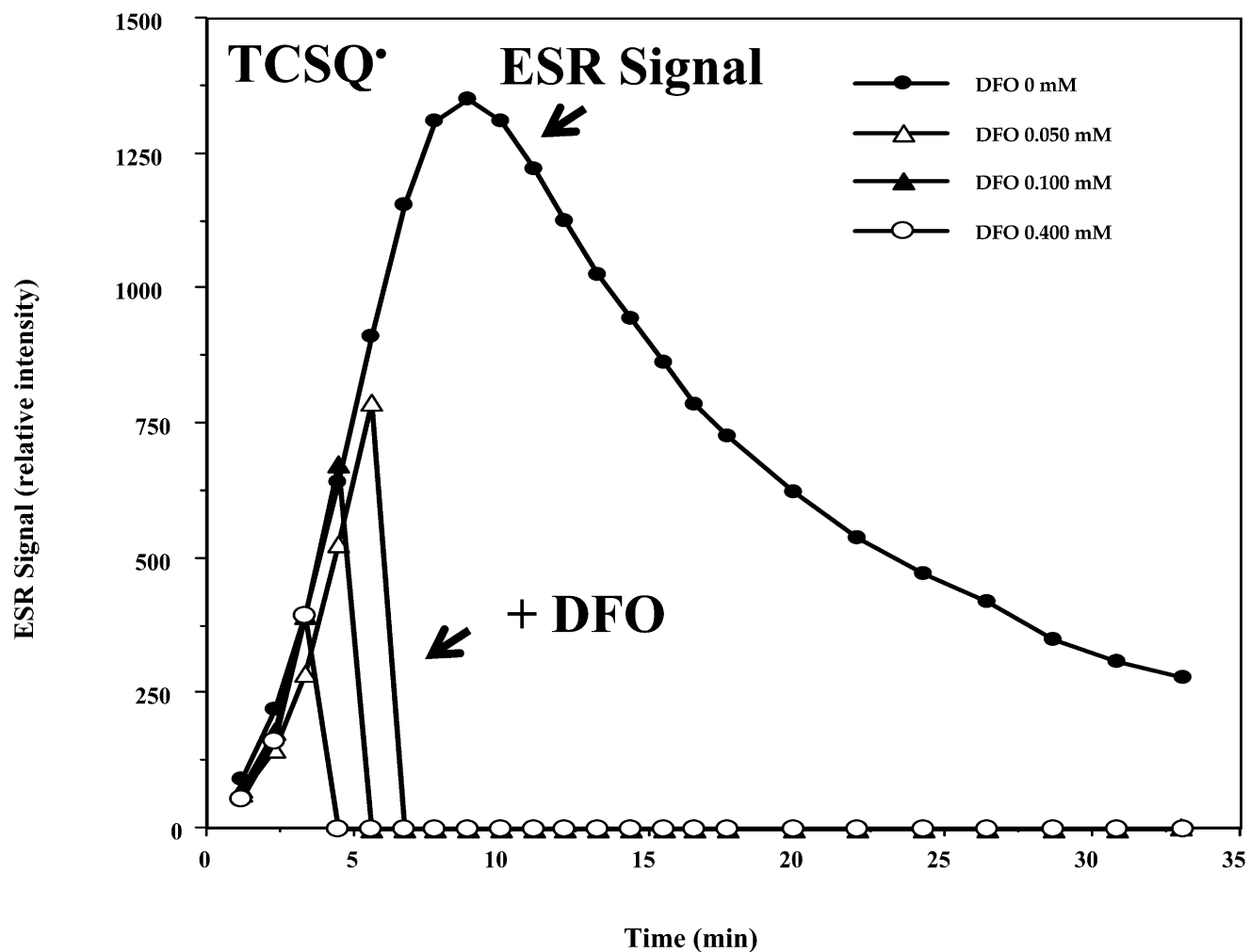

Figure 6. Inhibition of TCSQ formation by DFO (modified based on ref 32).

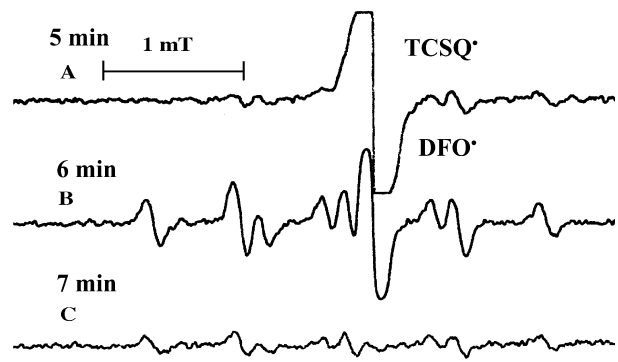

Figure 7. Decay of TCSQ ${ }^{*}$ was accompanied by the concurrent formation of DFO' (modified based on ref 32 ).

systems, recent studies demonstrated the ability of this trihydroxamate compound to act as a radical scavenger, in addition to and independent of its iron binding properties (for a summary, see ref 32). Diethylenetriaminepentaacetic acid (DTPA) is an analogue of the widely used chelating agent ethylenediaminetetraacetic acid (EDTA). DTPA could also form a kinetically and thermodynamically stable complex with ferric iron $(\log \beta$ $\left.=28 ; E^{\circ}=+0.03 \mathrm{~V}\right)$. Both DFO and DTPA have been widely used to study the role of iron in various chemical and biological systems; therefore, we employed these two structurally different but relatively specific iron chelating agents to probe whether iron played any role in TCHQ-induced DNA damage. We found (32) that DFO protected against TCHQ-induced DNA single strand breaks in isolated DNA, while other iron chelators such as DTPA did not (Figure 3). To better understand its underlying molecular mechanism, the autoxidation process of TCHQ yielding TCSQ ${ }^{\bullet}$ intermediate was studied in the presence and absence of these two iron chelating agents. We found that DFO led to a marked reduction in both the concentration and the half-life of TCSQ ${ }^{\circ}$. Interestingly, the decay of TCSQ ${ }^{\circ}$ was accompanied by concurrent formation of DFO-nitroxide radicals (DFO'), which contains the structural component $-\mathrm{CH}_{2}-$ $\mathrm{NO}^{*}-\mathrm{CO}-$ and gives a characteristic nine-line spectrum as a result of splitting of the nitroxide nitrogen coupling $\left(\mathrm{a}^{\mathrm{N}}=7.9\right.$

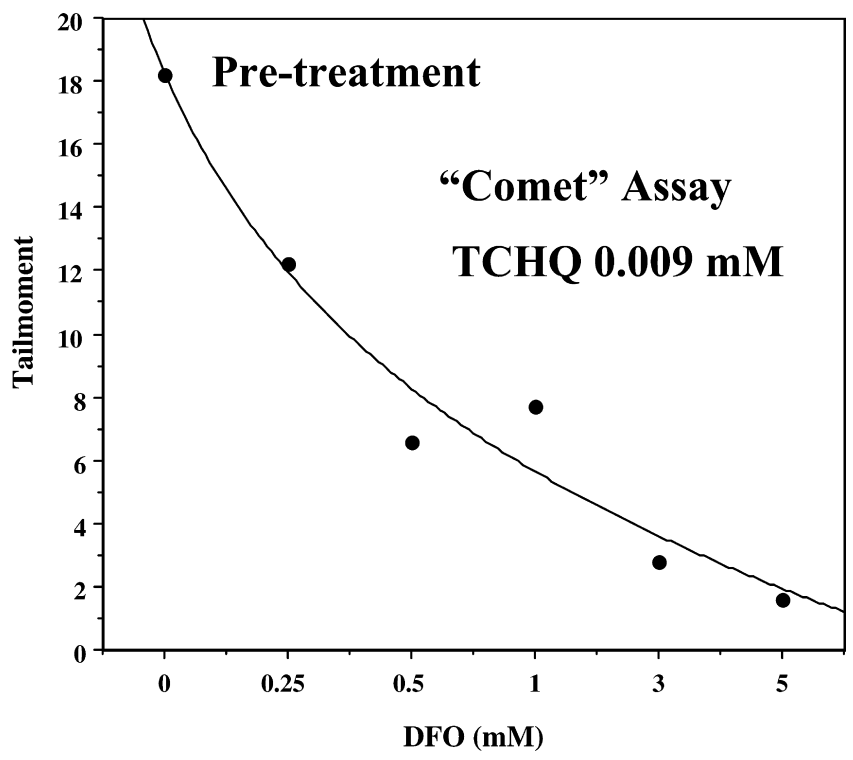

Figure 8. DFO protects against TCHQ-induced genotoxicity in human fibroblasts (modified based on ref 33).

G) by two protons $\left[\mathrm{a}(2)^{\mathrm{H}}=6.3 \mathrm{G}\right]$ from the neighboring $\mathrm{CH}_{2}$ group. These effects have been demonstrated by both UV-visible and electron spin resonance (ESR) spectral methods (Figure 4-7). In contrast, DTPA had no detectable effect on TCHQ autoxidation. These results suggest that the protection by DFO against TCHQ-induced DNA damage was not due to its binding of iron but rather due to its scavenging of the reactive TCSQ ${ }^{\circ}$ (32).

Interestingly, we found that DFO could also dramatically enhance the hydrolysis (dechlorination) of TCHQ (and TCBQ) to form chloranilic acid (2,5-dichloro-3,6-dihydroxy-1,4-benzoquinone, DDBQ) (32). The exact underlying molecular mechanism is currently under investigation in our laboratory, and we suspect that a novel Lossen rearrangement reaction might 


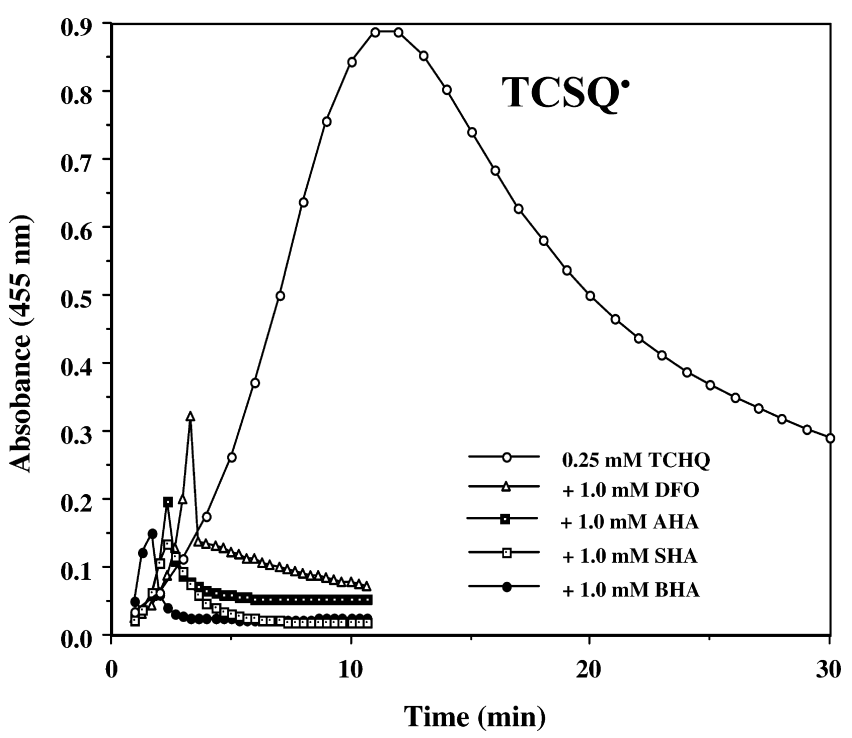

Figure 9. Inhibition of TCSQ formation by DFO and other hydroxamic acids (modified based on ref 33). AHA, SHA, and BHA represent aceto-, salicyl-, and benzo-hydroxamic acid, respectively.

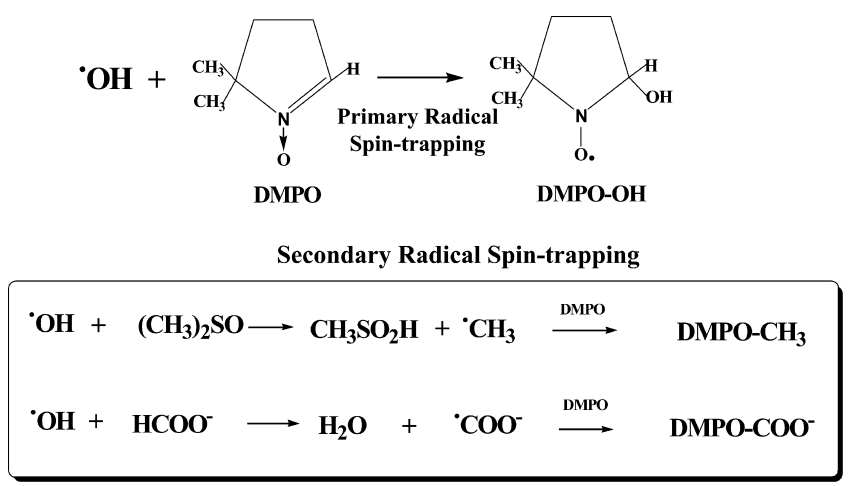

Figure 10. ${ }^{\circ} \mathrm{OH}$ detection by ESR spin-trapping method: primary and secondary radical spin trapping.

be involved. As compared to TCBQ, the DDBQ molecule was considered to be more stable, less reactive, and much less toxic; therefore, the enhanced formation of DDBQ from TCBQ catalyzed by DFO also contributed to its reduction of the toxicity of TCHQ. Furthermore, the enhanced conversion of TCHQ to DDBQ reduced the possibility of redox cycling between TCBQ and TCHQ in the cell, whereby repeatedly producing TCSQ:

2.2. Protection by DFO against TCHQ-Induced Cytoand Genotoxicity in Human Fibroblasts. Then, we extended our study from isolated DNA to human fibroblasts [cell line GM05757 from the Human Genetic Mutant Repository (Camden, NJ) were used] and from DFO to other hydroxamic acids. Cyto- and genotoxic effects of PCP metabolites were evaluated, respectively, by the MTT and "comet" assay (also called single cell gel electrophoresis). We found (33) that coincubation of DFO provided marked protection against both the cyto- and the genotoxicity induced by TCHQ. Pretreatment of the cells with DFO followed by washing also provided protection, although less efficiently as compared to the simultaneous treatment (Figure 8). Similar patterns of protection were also observed for three other hydroxamic acids: aceto-, benzo-, and salicyl-hydroxamic acid (AHA, BHA, and SHA). Spectral studies showed that the three hydroxamic acids tested other than DFO also effectively scavenged the reactive TCSQ and enhanced the formation of the less reactive and less toxic chloranilic acid (Figure 9). Dimethyl sulfoxide (DMSO), an efficient ${ }^{\circ} \mathrm{OH}$ scavenger, provided partial protection only at high
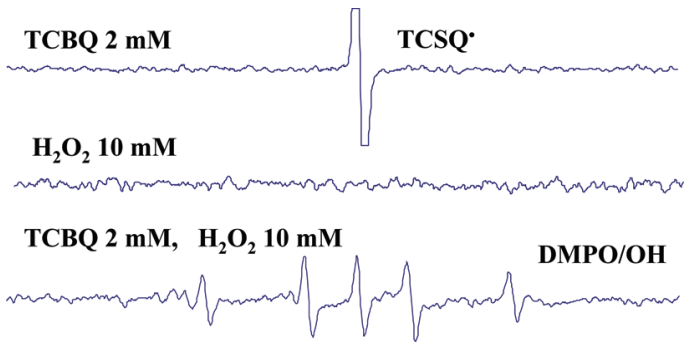

Figure 11. Production of ${ }^{\circ} \mathrm{OH}$ by TCBQ and $\mathrm{H}_{2} \mathrm{O}_{2}$. The central signal has been identified as TCSQ (modified based on ref 35 ).

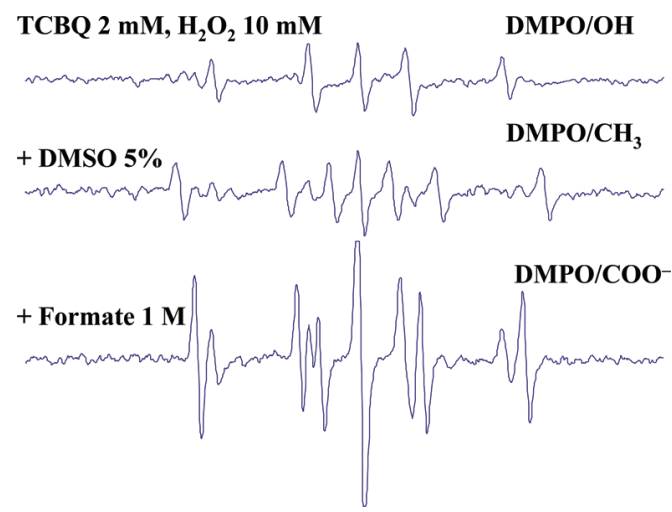

Figure 12. More definitive evidence for ${ }^{\circ} \mathrm{OH}$ production by TCBQ and $\mathrm{H}_{2} \mathrm{O}_{2}$ (modified based on ref 35 ).

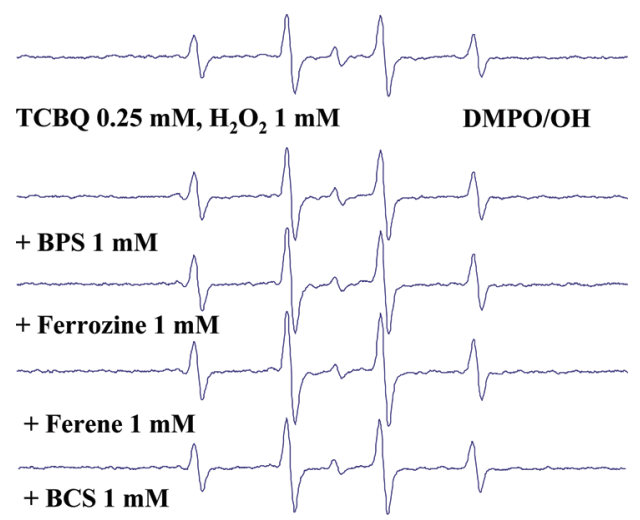

Figure 13. Metal chelators cannot inhibit ${ }^{\circ} \mathrm{OH}$ production by TCBQ and $\mathrm{H}_{2} \mathrm{O}_{2}$ (modified based on ref 35 ).

concentrations. The results of this study demonstrated that the protection provided by DFO and other hydroxamic acids against TCHQ-induced cyto- and genotoxicity in human fibroblasts is mainly through scavenging of the observed reactive TCSQ ${ }^{*}$ and not through prevention of the Fenton reaction by the binding of iron in a redox-inactive form (33).

\section{Molecular Mechanism of PCP Metabolite-Induced Genotoxicity}

3.1. Metal-Independent Production of ' $\mathrm{OH}$ by PCP Metabolite and $\mathrm{H}_{2} \mathrm{O}_{2}$. The above findings suggest that iron was not involved in TCHQ-induced DNA damage. In another word, TCHQ-induced DNA damage may not be due to the ironmediated ${ }^{\circ} \mathrm{OH}$ production through the classic Fenton reaction! Then, the question became what was the underlying molecular mechanism for PCP metabolites-mediated ${ }^{\circ} \mathrm{OH}$ production? To test whether ${ }^{\circ} \mathrm{OH}$ can be produced by $\mathrm{PCP}$ metabolites, we first employed the well-known salicylate hydroxylation method. HPLC with electrochemical detection was used to measure the levels of 2,3- and 2,5-dihydroxybenzoic acid (DHBA) formed when ${ }^{\circ} \mathrm{OH}$ reacts with salicylate. We found (34) that TCHQ 
and $\mathrm{H}_{2} \mathrm{O}_{2}$ could produce both 2,3- and 2,5-DHBA when incubated with salicylate. Their production was markedly inhibited by the ${ }^{\circ} \mathrm{OH}$ scavenging agents DMSO and ethanol. In contrast, their production was not affected by the nonhydroxamate iron chelators and the copper-specific chelator. Similar effects were also observed with TCBQ and $\mathrm{H}_{2} \mathrm{O}_{2}$. On the basis of these results, we suggested that ${ }^{\circ} \mathrm{OH}$ was produced by TCHQ and $\mathrm{H}_{2} \mathrm{O}_{2}$, possibly through a metal-independent Fenton-like reaction (34).

Because the salicylate hydroxylation method cannot provide direct evidence for ${ }^{\circ} \mathrm{OH}$ formation, a more specific method, such as secondary radical ESR spin trapping with 5,5-dimethyl-1pyrroline $\mathrm{N}$-oxide (DMPO), is needed to further substantiate and extend our previous observations. A typical DMPO/ $\mathrm{OH}$ signal, and $\mathrm{DMPO} /{ }^{\circ} \mathrm{CH}_{3}$ signal derived from ${ }^{\circ} \mathrm{OH}$ attack on DMSO, will be more conclusive evidence for ${ }^{\circ} \mathrm{OH}$ production from $\mathrm{H}_{2} \mathrm{O}_{2}$ and TCHQ or TCBQ (14) (Figure 10). We found (35) that when incubated with DMPO, TCBQ and $\mathrm{H}_{2} \mathrm{O}_{2}$ produced the DMPO/ ${ }^{\circ} \mathrm{OH}$ adduct. In contrast, incubation of either compound alone did not cause ${ }^{\circ} \mathrm{OH}$ formation (Figure 11). The formation of $\mathrm{DMPO} /{ }^{\circ} \mathrm{OH}$ was markedly inhibited by the ${ }^{\circ} \mathrm{OH}$ scavenging agents DMSO and formate, with the concomitant formation of the characteristic DMPO adducts with ${ }^{\circ} \mathrm{CH}_{3}$ and ${ }^{\circ} \mathrm{COO}^{-}$, respectively (Figure 12 ). These secondary radical ESR spin-trapping results provided definitive evidence that ${ }^{\circ} \mathrm{OH}$ could indeed be produced by TCBQ and $\mathrm{H}_{2} \mathrm{O}_{2}$.

Then, a critical question arose: Was the production of ${ }^{\circ} \mathrm{OH}$ by TCBQ and $\mathrm{H}_{2} \mathrm{O}_{2}$ metal-dependent or -independent? To answer this question, the potential role of catalytic transition metals contaminating the DMPO/TCBQ $/ \mathrm{H}_{2} \mathrm{O}_{2}$ reaction system was carefully examined by using several structurally different and relatively specific metal chelating agents for iron and copper $(36-38)$. Neither the $\mathrm{DMPO} /{ }^{\circ} \mathrm{OH}$ signal nor the $\mathrm{DMPO} /{ }^{\circ} \mathrm{CH}_{3}$ signal produced by the DMPO/TCBQ $/ \mathrm{H}_{2} \mathrm{O}_{2}$ system in the absence and presence, respectively, of DMSO was affected by the addition of various nonhydroxamate iron chelating agents, viz., bathophenanthroline disulfonate (BPS), ferrozine, and ferene, as well as the copper-specific chelating agent bathocuproine disulfonate (BCS) (Figure 13). In addition, no significant decrease in the $\mathrm{DMPO} /{ }^{\circ} \mathrm{OH}$ and $\mathrm{DMPO} /{ }^{\circ} \mathrm{CH}_{3}$ signal was observed by low concentrations $(\leq 10$ $\mu \mathrm{M})$ of the trihydroxamate iron chelating agent DFO. These DFO concentrations should be sufficient to chelate any trace amounts of iron contaminating the chelex-pretreated buffer. However, the formation of $\mathrm{DMPO} /{ }^{\circ} \mathrm{OH}$ and $\mathrm{DMPO} /{ }^{\circ} \mathrm{CH}_{3}$ was abolished by high concentrations of DFO ( $\geq 1 \mathrm{mM})$, with the concurrent formation of the DFO'. As discussed before, the inhibition of ${ }^{\circ} \mathrm{OH}$ production by DFO was not due to its iron-binding capacity but rather due to its ability to scavenge TCSQ'. Similar marked inhibition of DMPO/ ${ }^{\circ} \mathrm{OH}$ and DMPO/ ${ }^{\circ} \mathrm{CH}_{3}$ formation was observed with another TCSQ' scavenger, benzohydroxamic acid. In addition, even when trace amounts of iron [Fe(II), $0.5 \mu \mathrm{M}]$ were added to the DMPO/TCBQ/ $\mathrm{H}_{2} \mathrm{O}_{2}$ system, no increase in ${ }^{\circ} \mathrm{OH}$ production was observed.

In contrast, the formation of both $\mathrm{DMPO} /{ }^{\circ} \mathrm{OH}$ and $\mathrm{DMPO} /$ ${ }^{\circ} \mathrm{CH}_{3}$ by the $\mathrm{DMPO} / \mathrm{Fe}(\mathrm{II}) / \mathrm{H}_{2} \mathrm{O}_{2}$ system in the absence and presence, respectively, of DMSO was almost completely inhibited by the nonhydroxamate iron chelating agents BPS, ferrozine, and ferene, as well as the hydroxamate iron chelating agent DFO. No concurrent formation of the DFO` was detected, indicating that DFO acted by chelating iron in this classic Fenton system. These results clearly demonstrated that the production of ${ }^{\circ} \mathrm{OH}$ by TCBQ and $\mathrm{H}_{2} \mathrm{O}_{2}$ is independent of transition metal ions.

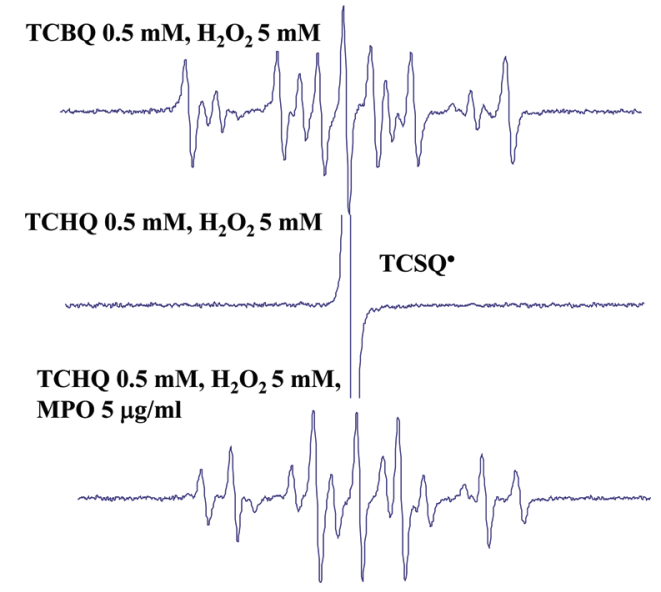

Figure 14. TCSQ ${ }^{\bullet}$ is not essential for ${ }^{\circ} \mathrm{OH}$ production by TCBQ and $\mathrm{H}_{2} \mathrm{O}_{2}$ (modified based on ref 45).

It should be noted that the metal-independent production of - $\mathrm{OH}$ was not limited to TCBQ and $\mathrm{H}_{2} \mathrm{O}_{2}$ but was also observed in the presence of other halogenated quinones, that is, 2-chloro-, 2,5-dichloro-, 2,6-dichloro-, trichloro-, tetrafluoro-, and tetrabromo-1,4-benzoquinone. In contrast, no ${ }^{\circ} \mathrm{OH}$ production was detected from $\mathrm{H}_{2} \mathrm{O}_{2}$ and the nonhalogenated quinone, 1,4benzoquinone, and the methyl-substituted quinones 2,6-dimethyl- and tetramethyl-1,4-benzoquinone (35).

3.2. Molecular Mechanism of Metal-Independent Production of ${ }^{\circ} \mathrm{OH}$ by PCP Metabolites and $\mathrm{H}_{2} \mathrm{O}_{2}$. On the basis of the above experimental results, we first proposed $(34,35)$ that the production of ${ }^{\circ} \mathrm{OH}$ by TCBQ and $\mathrm{H}_{2} \mathrm{O}_{2}$ might be through a metal-independent semiquinone-mediated organic Fenton reaction:

$$
\mathrm{TCSQ}^{\bullet}+\mathrm{H}_{2} \mathrm{O}_{2} \rightarrow{ }^{\bullet} \mathrm{OH}+\mathrm{OH}^{-}+\mathrm{TCBQ}
$$

where TCSQ ${ }^{\bullet}$ substitutes for ferrous iron in the classic, metaldependent Fenton reaction. This type of reaction between semiquinone radicals and $\mathrm{H}_{2} \mathrm{O}_{2}$ has been previously proposed by Koppenol and Butler (39), who suggested that if a quinone/ semiquinone couple has a reduction potential of between -330 and $+460 \mathrm{mV}$, it can theoretically bring about a metalindependent Fenton reaction. It was suggested that such reactions are thermodynamically feasible and do not require metal ions for catalysis $(39,40)$, which might be the case in this study, where the reduction potentials of the quinone/semiquinone couples for 2-chloro-, 2,5-dichloro-, tetrafluoro-, tetrabromo-, and tetrachloro-1,4-benzoquinone are $-100,+60,+200,+240$, and $+250 \mathrm{mV}$, respectively (41). These values are within the suggested range of -330 to $+460 \mathrm{mV}$. In contrast, the reduction potentials for 2,6-dimethyl-1,4-benzoquinone and tetramethyl1,4-benzoquinone of -430 and $-600 \mathrm{mV}$, respectively (41), are outside this range, and indeed, no ${ }^{\circ} \mathrm{OH}$ formation could be detected.

If the above mechanism was correct, then the production of 'OH from $\mathrm{H}_{2} \mathrm{O}_{2}$ and TCBQ should be dependent on the concentration of TCSQ; that is, the higher the concentration of TCSQ', the more ${ }^{\circ} \mathrm{OH}$ should be produced. Furthermore, the main product of this reaction should be TCBQ. Using secondary radical ESR spin-trapping method, we found that $\mathrm{DMPO} /{ }^{\circ} \mathrm{CH}_{3}$ and DMPO/ ${ }^{\circ} \mathrm{OH}$ adducts can be produced by $\mathrm{H}_{2} \mathrm{O}_{2}$ and TCBQ in the presence of the spin-trapping agent DMPO and ${ }^{\circ} \mathrm{OH}$ scavenger DMSO. However, no DMPO/ ${ }^{\circ} \mathrm{CH}_{3}$ and $\mathrm{DMPO} /{ }^{\circ} \mathrm{OH}$ adducts were detected from $\mathrm{H}_{2} \mathrm{O}_{2}$ and TCHQ (the reduced form of TCBQ), although high concentrations of TCSQ could be produced during the autoxidation of TCHQ. Interestingly, if 

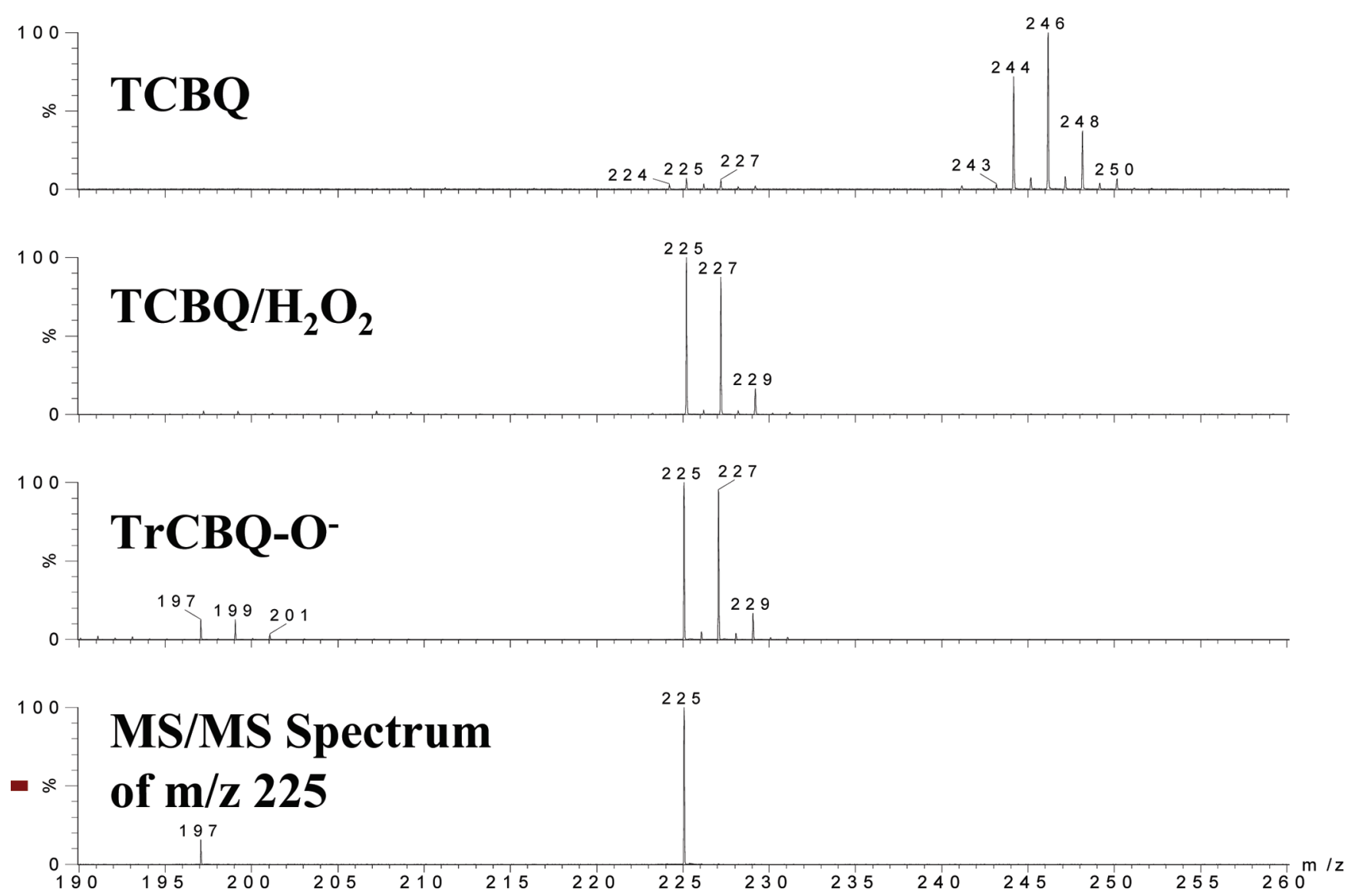

Figure 15. Mass spectral identification of the reaction product between TCBQ and $\mathrm{H}_{2} \mathrm{O}_{2}$ (modified based on ref 45).

TCHQ was quickly oxidized to TCBQ with myeloperoxidase (MPO), DMPO/ ${ }^{\circ} \mathrm{CH}_{3}$ and $\mathrm{DMPO} /{ }^{\circ} \mathrm{OH}$ adducts could be detected again, similar to that produced by TCBQ (Figure 14). Furthermore, the formation of DMPO/ ${ }^{\circ} \mathrm{CH}_{3}$ and $\mathrm{DMPO} /{ }^{\circ} \mathrm{OH}$ was found to be directly dependent on the concentrations of TCBQ and $\mathrm{H}_{2} \mathrm{O}_{2}$. These results strongly suggest that TCBQ, but not its corresponding semiquinone radical TCSQ', is essential for ${ }^{\circ} \mathrm{OH}$ production. Therefore, the production of ${ }^{\circ} \mathrm{OH}$ by TCBQ and $\mathrm{H}_{2} \mathrm{O}_{2}$ appears not to occur through a semiquinone-dependent organic Fenton reaction.

To get more information on the mechanism of ${ }^{\circ} \mathrm{OH}$ production by $\mathrm{TCBQ} / \mathrm{H}_{2} \mathrm{O}_{2}$, the time- and concentration-dependent production of DMPO/ ${ }^{\circ} \mathrm{OH}$ by TCBQ $/ \mathrm{H}_{2} \mathrm{O}_{2}$ was studied. Two distinct phases were observed as follows: the first fast phase (about $30 \mathrm{~s}$ ) and the second slower phase. This indicates that ${ }^{\circ} \mathrm{OH}$ may be produced by two-step reactions between TCBQ and $\mathrm{H}_{2} \mathrm{O}_{2}$. When the TCBQ concentration was fixed at $0.1 \mathrm{mM}$, the rate of DMPO/ $/{ }^{\circ} \mathrm{OH}$ production was dependent on the $\mathrm{H}_{2} \mathrm{O}_{2}$ concentration. It should be noted that $\mathrm{DMPO} /{ }^{\circ} \mathrm{OH}$ could be detected at $\mathrm{H}_{2} \mathrm{O}_{2}$ concentration as low as $10 \mu \mathrm{M}$. When the $\mathrm{H}_{2} \mathrm{O}_{2}$ concentration was fixed at $0.1 \mathrm{mM}, \mathrm{DMPO} /{ }^{\circ} \mathrm{OH}$ could be detected at a TCBQ concentration as low as $5 \mu \mathrm{M}$. Furthermore, UV-visible spectral studies showed that there was a direct interaction between TCBQ and $\mathrm{H}_{2} \mathrm{O}_{2}$, with the reaction mixture changing quickly from the original yellow color $\left(\lambda_{\max }=292 \mathrm{~nm}\right)$ to a characteristic purple color $\left(\lambda_{\max }=295\right.$ and $\left.535 \mathrm{~nm}\right)$ in phosphate buffer ( $\mathrm{pH}$ 7.4). The final reaction products between TCBQ and $\mathrm{H}_{2} \mathrm{O}_{2}$ were then identified by electrospray ionization quadrupole time-of-flight mass spectrometry (ESI-Q-TOF-MS). The mass spectrum of TCBQ is characterized by a four-chlorine isotope cluster at $\mathrm{m} / \mathrm{z}, 246$ and traces of a three-chlorine isotope cluster at $m / z$ 227. The addition of $\mathrm{H}_{2} \mathrm{O}_{2}$ to TCBQ led to complete disappearance of the molecular ion peak clusters at $\mathrm{m} / \mathrm{z}, 246$ and a dramatic increase of the peak clusters at $m / z$ 227. Tandem mass spectrometric analysis showed that the peak at $\mathrm{m} / \mathrm{z} 227$ could be fragmented to form the peak at $m / z$ 197, which suggests that the peak at $\mathrm{m} / \mathrm{z} 197$ is solely derived from the peak at $\mathrm{m} / \mathrm{z}$, 227 (Figure 15). These results indicate that the major reaction product between TCBQ and $\mathrm{H}_{2} \mathrm{O}_{2}$ was probably the ionic form of trichloro-hydroxy-1,4-benzoquinone (TrCBQ-OH). This was further confirmed by comparison with the authentic TrCBQ$\mathrm{OH}$ synthesized according to a published method (42), which showed the same ESI-MS profile and the same retention time in HPLC.

To better understand the source and origin of the oxygen atom inserted into the reaction product TrCBQ-OH formed from the reaction between $\mathrm{H}_{2} \mathrm{O}_{2}$ and TCBQ, TCBQ was incubated with oxygen-18-enriched $\mathrm{H}_{2} \mathrm{O}_{2}\left(\left[{ }^{18} \mathrm{O}\right]-\mathrm{H}_{2} \mathrm{O}_{2}\right)$. The mass spectra of the molecular ion region of deprotonated $\mathrm{TrCBQ}-\mathrm{OH}$, obtained with unlabeled and labeled $\mathrm{H}_{2} \mathrm{O}_{2}$, demonstrated the shift of the molecular ion isotope cluster peaks of the unlabeled compound with 2 mass units, as could be expected for the incorporation of ${ }^{18} \mathrm{O}$. These results indicate that $\mathrm{H}_{2} \mathrm{O}_{2}$ is the source and origin of the oxygen atom inserted into the reaction product TrCBQ$\mathrm{OH}$.

It has also been shown (43) that both TCBQ and $\mathrm{H}_{2} \mathrm{O}_{2}$ were consumed with a stoichiometric ratio of about $1: 1$, and $\mathrm{H}_{2} \mathrm{O}_{2}$ accelerated the rate of TCBQ decomposition by 2 orders of magnitude with the loss of chloride. Thus, the metal-independent production of ${ }^{\circ} \mathrm{OH}$ by TCBQ and $\mathrm{H}_{2} \mathrm{O}_{2}$ may not be through a previously proposed semiquinone-mediated organic Fenton reaction. On the basis of the above experimental results and the fact that $\mathrm{H}_{2} \mathrm{O}_{2}$ is a better nucleophile than $\mathrm{H}_{2} \mathrm{O}$ (44), we proposed a novel mechanism for ${ }^{\circ} \mathrm{OH}$ production by $\mathrm{H}_{2} \mathrm{O}_{2}$ and TCBQ (45) (Figure 16): A nucleophilic reaction may take place between TCBQ and $\mathrm{H}_{2} \mathrm{O}_{2}$, forming an unstable trichloro- 


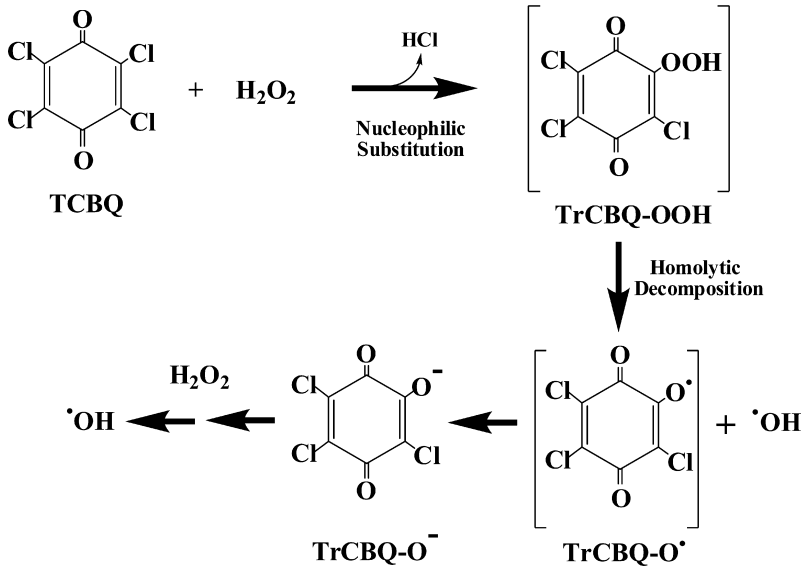

Figure 16. Proposed novel mechanism for ${ }^{\circ} \mathrm{OH}$ production by TCBQ and $\mathrm{H}_{2} \mathrm{O}_{2}$ (modified based on ref 45).

hydroperoxyl-1,4-benzoquinone (TrCBQ-OOH) intermediate, which can decompose homolytically to produce ${ }^{\circ} \mathrm{OH}$ and trichloro-hydroxy-1,4-benzoquinone radical (TrCBQ-O'). TrCBQ$\mathrm{O}^{\bullet}$ then may disproportionate to form the ionic form of trichlorohydroxy-1,4-benzoquinone $\left(\mathrm{TrCBQ}-\mathrm{O}^{-}\right)$. In the presence of excess of $\mathrm{H}_{2} \mathrm{O}_{2}$, TrCBQ- ${ }^{-}$may further react with $\mathrm{H}_{2} \mathrm{O}_{2}$ via a similar pathway to produce another ${ }^{\circ} \mathrm{OH}$. We also found that TCBQ and other halogenated quinones such as 2,5-dichloro1,4-benzoquinone (DCBQ) could enhance the decomposition of organic hydroperoxides such as $t$-butylhydroperoxide and formation of alkoxyl radicals in a similar mechanism (46).

\section{Conclusions}

These findings represent a novel mechanism of ${ }^{\circ} \mathrm{OH}$ and alkoxyl radical formation not requiring the involvement of redox-active transition metal ions and may partly explain the potential carcinogenicity of not only PCP but also other widely used polyhalogenated aromatic compounds such as 2,4,6- and 2,4,5-trichlorophenol, hexachlorobenzene, Agent Orange [the mixture of 2,4,5-trichlorophenoxyacetic acid (2,4,5-T) and 2,4dichlorophenoxyacetic acid (2,4-D)], and the brominated flameretardant 3,3',5,5'-tetrabromobisphenol A (TBBPA), since these compounds can be metabolized in vivo $(47,48)$ or dechlorinated chemically (49-52) to tetra-, di-, or monohalogenated quinones. Our data suggest that TCBQ and other halogenated quinones may react with hydroperoxides and exert toxic effects through enhanced production of hydroxyl/alkoxyl radicals and hence increased DNA, protein, and lipid oxidation.

It should be noted, however, that many questions still need to be addressed, especially regarding the biological relevance of the reactions under study. For example: What is the rate constant for the reaction between TCBQ and $\mathrm{H}_{2} \mathrm{O}_{2}$ and could it be able to compete with the classic Fenton reaction? How does the reaction of the quinone with $\mathrm{H}_{2} \mathrm{O}_{2}$ compare kinetically with reactions with other good nucleophiles such as glutathione and other thiols, which are present at high concentrations in vivo? How rapid is the decomposition of the quinone-peroxide adduct? How efficient is the radical formation from a given amount of adduct; that is, how well do other pathways compete with this reaction? Could ${ }^{\circ} \mathrm{OH}$ produced by this pathway be detected in cell culture or even in an animal model? Therefore, further investigations are needed to study whether these reactions occur and are relevant under physiological conditions or in vivo.

Acknowledgment. The work in this paper was supported by Project 973 (2008CB418106), the Hundred-Talent Project, CAS;
NSFC Grant (20777080, 20877081, 20747001, 20890112, and 20621703); Project 973 (2008CB418106); and NIH Grants ES11497, RR01008, and ES00210. I thank all of those who helped advance this research, especially Drs. Modechai Chevion, Irene Witte, Balz Frei, Balaraman Kalyanaraman, Ying-Jan Wang, Hong-Tao Zhao, Ronald P. Mason, Garry R. Buettner, Enrique Cadenas, Barry Halliwell, Yu-Guo Du, Gui-Bin Jiang, Keith U. Ingold, Jack Helpern, Irwin Fridovich, Earl R. Stadtman, and those peer reviewers who provided constructive suggestions and advice.

\section{References}

(1) IARC (1991) Pentachlorophenol. IARC Monographs on the Evaluation of Carcinogenic Risks to Humans: Occupational Exposures in Insecticide Application, and Some Pesticides, Vol. 53, pp 371-402, IARC, Lyon, France.

(2) Seiler, J. P. (1991) Pentachlorophenol. Mutat. Res. 257, $27-47$.

(3) Rao, K. R., Ed. (1987) Pentachlorophenol: Chemistry, Pharmacology, and Environmental Toxicology, Plenum, New York.

(4) McConnell, E. E., Huff, J. E., Hejtmancik, M., Peters, A. C., and Persing, R. (1991) Toxicology and carcinogenesis studies of two grades of pentachlorophenol in B6C3F1 mice. Fundam. Appl. Toxicol. 17, 519-532.

(5) Chhabra, R. S., Maronpot, R. M., Bucher, J. R., Haseman, J. K., Toft, J. D., and Hejtmancik, M. R. (1999) Toxicology and carcinogenesis studies of pentachlorophenol in rats. Toxicol. Sci. 48, 14-20.

(6) Renner, G., and Mucke, W. (1986) Transformations of pentachlorophenol. Part I: Metabolism in animals and man. Toxicol. Environ. Chem. 11, 9-29.

(7) Renner, G., and Hopfer, C. (1990) Metabolic studies of pentachlorophenol (PCP) in rats. Xenobiotica 20, 573-582.

(8) Reigner, B. G., Rigod, J. F., and Tozer, T. N. (1992) Disposition, bioavailability, and serum protein binding of pentachlorophenol in the B6C3F1 mouse. Pharmacol. Res. 9, 1053-1057.

(9) Lin, P. H., Waidyanatha, S., Pollack, G. M., and Rappaport, S. M. (1997) Dosimetry of chlorinated quinone metabolites of pentachlorophenol in the livers of rats and mice based upon measurement of protein adducts. Toxicol. Appl. Pharmacol. 145, 399-408.

(10) Tsai, C. H., Lin, P. H., Waidyanatha, S., and Rappaport, S. M. (2002) Fractionation of protein adducts in rats and mice dosed with $\left[{ }^{14} \mathrm{C}\right]$ pentachlorophenol. Arch. Toxicol. 76, 628-633.

(11) Carstens, C. P., Blum, J. K., and Witte, I. (1990) The role of hydroxyl radicals in tetrachloro-hydroquinone induced DNA strand break formation in PM2 DNA and human fibroblasts. Chem-Biol. Interact. 74, 305-314.

(12) Bolton, J. L., Trush, M. A., Penning, T. M., Dryhurst, G., and Monks, T. J. (2000) Role of quinones in toxicology. Chem. Res. Toxicol. 13, $135-160$.

(13) O'Brien, P. J. (1991) Molecular mechanisms of quinone cytotoxicity. Chem.-Biol. Interact. 80, 1-41.

(14) Halliwell, B., and Gutteridge, J. M. C. (2007) Free Radicals in Biology and Medicine, Oxford University Press: New York.

(15) Witte, I., Juhl, U., and Butte, W. 19850 DNA-damaging properties and cytotoxicity in human fibroblasts of tetrachlorohydroquinone, a pentachlorophenol metabolite. Mutat. Res. 145, 71-75.

(16) Dahlhaus, M., Almstadt, E., Henachke, P., Luttgert, S., and Appel, K. E. (1996) Oxidative DNA lesions in V79 cells mediated by pentachlorophenol metabolites. Arch. Toxicol. 70, 457-460.

(17) Ehrlich, W. (1990) The effect of pentachlorophenol and its metabolite tetrachlorohydroquinone on cell growth and the induction of DNA damage in Chinese hamster ovary cells. Mutat. Res. 244, 299-302.

(18) Dahlhaus, M., Almstadt, E., and Appel, K. E. (1994) The pentachlorophenol metabolite tetrachloro- $p$-hydroquinone induces the formation of 8-hydroxy-2-deoxyguanosine in liver DNA of male B6C3F1 mice. Toxicol. Lett. 74, 265-274.

(19) Wang, Y. J., Ho, Y. S., Chu, S. W., Lien, H. J., Liu, T. H., and Lin, J. K. (1997) Induction of glutathione depletion, p53 protein accumulation and cellular transformation by tetrachlorohydroquinone, a toxic metabolite of pentachlorophenol. Chem.-Biol. Interact. 105, 1-16.

(20) Jansson, K., and Jansson, V. (1992) Induction of micronuclei in V79 Chinese hamster cells by tetrachlorohydroquinone, a metabolite of pentachlorophenol. Mutat. Res. 279, 205-208.

(21) Purschke, M., Jacobi, H., and Witte, I. (2002) Differences in genotoxicity of $\mathrm{H}_{2} \mathrm{O}_{2}$ and tetrachlorohydroquinone in human fibroblasts. Mutat. Res. 513, 159-167.

(22) Dahlhaus, M., Almstadt, E., Henschke, P., Luttgert, S., and Appel, K. E. (1995) Induction of 8-hydroxy-2-deoxyguanosine and single strand breaks in DNA of V79 cells by tetrachloro- $p$-hydroquinone. Mutat. Res. 329, 29-36. 
(23) Lin, P. H., Nakamura, J., Yamaguchi, S., La, D. K., Upton, P. B., and Swenberg, J. A. (2001) Induction of direct adducts, apurinic/apyrimidinic sites and oxidized bases in nuclear DNA of human HeLa S3 tumor cells by tetrachlorohydroquinone. Carcinogenesis 22, 635-639.

(24) Lin, P. H., La, D. K., Upton, P. B., and Swenberg, J. A. (2002) Analysis of DNA adducts in rats exposed to pentachlorophenol. Carcinogenesis $23,365-369$

(25) Breen, A. P., and Murphy, J. A. (1995) Reactions of oxyl radicals with DNA. Free Radical Biol. Med. 18, 1033-1077.

(26) Balasubramanian, B., Pogozelski, W. K., and Tullius, T. D. (1998) DNA strand breaking by the hydroxyl radical is governed by the accessible surface areas of the hydrogen atoms of the DNA backbone. Proc. Natl. Acad. Sci. U.S.A. 95, 9738-9743.

(27) Nakamura, J., La, D. K., and Swenberg, J. A. (2000) 5'-Nicked apurinic/apyrimidinic sites are resistant to $\beta$-elimination by $\beta$-polymerase and are persistent in human cultured cells after oxidative stress. J. Biol. Chem. 275, 5323-5328.

(28) Lin, P. H., Nakamura, J., Yamaguchi, S., La, D. K., Upton, P. B., and Swenberg, J. A. (2001) Oxidative damage and direct adducts in calf thymus DNA induced by tetrachlorohydroquinone and tetrachloro1,4-benzoquinone. Carcinogenesis 22, 627-634.

(29) Bodell, W. J., Ye, Q., Pathak, D. N., and Pongracz, K. (1998) Oxidation of eugenol to form DNA adducts and 8-hydroxy-2'-deoxyguanosine: Role of quinone methide derivative in DNA adduct formation. Carcinogenesis 19, 437-443.

(30) Lin, Y. P., Zhu, B. Z., Yang, M. C., Frei, B., Pan, M. S., Lin, J. K., and Wang, Y. J. (2004) Bcl-2 over-expression inhibits pentachlorophenol metabolite-induced apoptosis in NIH3T3 cells: A possible mechanism for tumor promotion. Mol. Carcinog. 40, 24-33.

(31) Sai-Kato, K., Umemura, T., Takagi, A., Hasegawa, R., Tanimura, A., and Kurokawa, Y. (1995) Pentachlorophenol-induced oxidative DNA damage in mouse liver and protective effect of antioxidants. Food Chem. Toxicol. 33, 877-882.

(32) Zhu, B. Z., Har-El, R., Kitrossky, N., and Chevion, M. (1998) New modes of action of desferrioxamine: Scavenging of semiquinone radical and stimulation of hydrolysis of tetrachlorohydroquinone. Free Radical Biol. Med. 24, 360-369.

(33) Witte, I., Zhu, B. Z., Lueken, A., Magnani, D., Stossberg, H., and Chevion, M. (2000) Protection by desferrioxamine and other hydroxamic acids against tetrachlorohydroquinone-induced cyto- and genotoxicity in human fibroblasts. Free Radical Biol. Med. 28, 693-700.

(34) Zhu, B. Z., Kitrossky, N., and Chevion, M. (2000) Evidence for production of hydroxyl radicals by pentachlorophenol metabolites and hydrogen peroxide: A metal-independent organic Fenton reaction. Biochem. Biophys. Res. Commun. 270, 942-946.

(35) Zhu, B. Z., Zhao, H. T., Kalyanaraman, B., and Frei, B. (2002) Metalindependent production of hydroxyl radicals by chlorinated quinones and hydrogen peroxide: An ESR spin-trapping study. Free Radical Biol. Med. 32, 465-473.

(36) Mohindru, A., Fisher, J. M., and Rabinowitz, M. (1983) Bathocuproine sulphonate: A tissue culture-compatible indicator of copper-mediated toxicity. Nature (London) 303, 64-65.
(37) Graf, E., Mahoney, J. R., Bryant, R. G., and Eaton, J. W. (1984) Ironcatalyzed hydroxyl radical formation. Stringent requirement for free iron coordination site. J. Biol. Chem. 259, 3620-3624.

(38) Dean, R. T., and Nicholson, P. (1994) The action of nine chelators on iron-dependent radical damage. Free Radical Res. 20, 83-101.

(39) Koppenol, W. H., and Butler, J. (1985) Energetics in interconversion reactions of oxyradicals. Adv. Free Radical Biol. Med. 1, 91-131.

(40) Nohl, H., and Jordan, W. (1987) The involvement of biological quinones in the formation of hydroxyl radicals via the Haber-Weiss reaction. Bioorg. Chem. 15, 374-382.

(41) Peover, M. E. (1962) A polarographic investigation into the redox behavior of quinones: The role of electron affinity and solvent. J. Chem. Soc. 4540-4549.

(42) Hancock, J. W., Morrell, C. E., and Rhum, D. (1962) Trichlorohydroquinone. Tetrahedron Lett. 22, 987-988.

(43) Sarr, D. H., Kazunga, C., Charles, M. J., Pavlovich, J. G., and Aitken, M. D. (1995) Decomposition of tetrachloro-1,4-benzoquinone $(P$ chloranil) in aqueous solution. Environ. Sci. Technol. 29, 2735-2740.

(44) Curci, R., and Edwards, J. O. (1992) Activation of hydrogen peroxide by organic compounds. In Catalytic Oxidations with Hydrogen Peroxide as Oxidant (Strukul, G., Ed.) pp 57-60, Kluwer Academic Publishers, Dordrecht.

(45) Zhu, B. Z., Kalyanaraman, B., and Jiang, G. (2007) Molecular mechanism for metal-independent production of hydroxyl radicals by hydrogen peroxide and halogenated quinones. Proc. Natl. Acad. Sci. U.S.A. 104, 17575-17578.

(46) Zhu, B. Z., Zhao, H. T., Kalyanaraman, B., Liu, J., Shan, G. Q., Du, Y. G., and Frei, B. (2007) Mechanism of metal-independent decomposition of organic hydroperoxides and formation of alkoxyl radicals by halogenated quinones. Proc. Natl. Acad. Sci. U.S.A. 104, 36983702.

(47) Haugland, R. A., Schlemm, D. J., Lyons, R. P., 3rd., Sferra, P. R., and Chakrabarty, A. M. (1990) Degradation of the chlorinated phenoxyacetate herbicides 2,4-dichlorophenoxyacetic acid and 2,4,5trichlorophenoxyacetic acid by pure and mixed bacterial cultures. Appl. Environ. Microbiol. 56, 1357-1362.

(48) Chignell, C. F., Han, S. K., Mouithys-Mickalad, A., Sik, R. H., Stadler, K., and Kadiiska, M. B. (2008) EPR studies of in vivo radical production by $3,3^{\prime}, 5,5^{\prime}$-tetrabromobisphenol A (TBBPA) in the Sprague-Dawley rat. Toxicol. Appl. Pharmacol. 230, 17-22.

(49) Song, Y., Wagner, B. A., Lehmler, H. J., and Buettner, G. R. (2008) Semiquinone radicals from oxygenated polychlorinated biphenyls: Electron paramagnetic resonance studies. Chem. Res. Toxicol. 21, 1359-1367.

(50) Meunier, B. (2002) Catalytic degradation of chlorinated phenols. Science 296, 270-271.

(51) Gupta, S. S., Stadler, M., Noser, C. A., Ghosh, A., Steinhoff, B., Lenoir, D., Horwitz, C. P., Schramm, K. W., and Collins, T. J. (2002) Rapid total destruction of chlorophenols by activated hydrogen peroxide. Science 296, 326-328.

(52) Sorokin, A., Meunier, B., and Séris, J. L. (1995) Efficient oxidative dechlorination and aromatic ring cleavage of chlorinated phenols catalyzed by iron sulfophthalocyanine. Science 268, 1163-1166. 